\title{
Synthesis of Folate-Appended $\beta$-Cyclodextrin Using Phenanthroline as Linker for Cancer Targeting Drug Delivery
}

\author{
Nadim S. Russel ${ }^{1}$, Punam K. Paul ${ }^{1}$, Mohammad Karim ${ }^{1 *}$, Byeongwoon Song2 ${ }^{*}$ \\ ${ }^{1}$ Department of Chemistry, Tennessee State University, Nashville, USA \\ ${ }^{2}$ Department of Microbiology, Immunology, and Physiology, Meharry Medical College, Nashville, USA \\ Email: ^mkarim@tnstate.edu, *bsong@mmc.edu
}

How to cite this paper: Russel, N.S., Paul, P.K., Karim, M. and Song, B. (2019) Synthesis of Folate-Appended $\beta$-Cyclodextrin Using Phenanthroline as Linker for Cancer Targeting Drug Delivery. International Journal of Organic Chemistry, 9, 47-66. https://doi.org/10.4236/ijoc.2019.91005

Received: January 24, 2019

Accepted: March 12, 2019

Published: March 15, 2019

Copyright () 2019 by author(s) and Scientific Research Publishing Inc. This work is licensed under the Creative Commons Attribution International License (CC BY 4.0).

http://creativecommons.org/licenses/by/4.0/

(c) (i) Open Access

\begin{abstract}
Here we have synthesized cancer targeting drug delivery system that contains $\beta$-cyclodextrin as a drug carrier and folic acid as a targeting ligand. Folic acid was selected as a cancer targeting ligand because folic acid receptors are highly expressed in a variety of tumor types. $\beta$-cyclodextrin and folic acid were connected through a linker [1,10-phenanthroline or 5-(hydroxymethyl) furfural]. $\beta$-cyclodextrin and folic acid were attached to the linker by formation of Schiffbase and ester, respectively. Our targeted synthetic products were confirmed by NMR, Mass and IR spectroscopy. We anticipate that our synthetic products can confer cancer cell-specific drug delivery as well as desired properties such as nanoparticle formation.
\end{abstract}

\section{Keywords}

Schiff Base, $\beta$-Cyclodextrin, $p$-Toluenesulfonylchloride, Ethylenediamine,

Folic Acid, 2,9-Dimethyl-1,10-Phenanthroline Hemi-Hydrate,

5-(Hydroxymethyl-2-Furaldehyde)

\section{Introduction}

Cyclodextrins (CDs) are cyclic oligosaccharides generated from starch (e.g. corn, potato) and $\beta$-cyclodextrin is one type of cyclodextrin that contains 7 glucose units in its structure [1]. The hydrophobic central cavity and the hydrophilic outer surface allow $\mathrm{CDs}$ to form water-soluble inclusion complexes with several drug molecules or compounds and help to protect the guest molecules from oxidation and degradation and to increase their solubility and bioavailability. Thus, CDs are frequently used as a drug carrier.

Hybrid delivery system for effective transportation of temoporfin was sug- 
gested by Yakayets et al. and proposed to achieve drug-in-cyclodextrin-in-liposome (DCL) nanoconstructs [2]. They also found that DCLs were stable and almost all temoporfin or mTHPC was bound to $\beta$-CDs in the inner aqueous liposome core. Among all tested DCLs, trimethyl- $\beta$-CD-based DCL demonstrated a homogenous accumulation of mTHPC across tumor spheroid volume, thus supposing optimal mTHPC distribution.

Hyun prepared a $\beta$-cyclodextrin ( $\beta$-CD)-based carrier consisting of $\beta$-CD, polyethylene glycol (PEG) and folic acid (FA) (CDPF) for improved doxorubicin (DOX) delivery to breast cancer in vitro and in vivo [3]. The results of Hyun's study suggested that CDPF can maximize the efficacy of DOX delivery; therefore can be used as a good candidate for developing optimal drug delivery systems.

The purpose of study carried out by Khaid et al. was to develop and characterize hydroxypropyl- $\beta$-cyclodextrin ( $\mathrm{HP} \beta \mathrm{CD}$ ) hybrid nanogels for solubility enhancement of lipophilic drug, dexibuprofen [4]. HP $\beta$ CD hybrid nanogels were designed by crosslinking of hydroxypropyl- $\beta$-cyclodextrin with 2-acrylamido-2Methylpropane sulfonic acid (AMPS) via free radical polymerization. Efficient solubilization of dexibuprofen has been observed by HP $\beta C D$ hybrid nanogels. Highly porous and amorphous nanogels showed a significant dexibuprofen release in aqueous medium.

Another novel drug delivery system was introduced by Kong's group based on binary solvent gel in which both hydrophobic and hydrophilic drugs could be loaded into the gel without altering the gelation property of the native system [5]. The gel was simply prepared from native $\beta$-cyclodextrin $(\beta-\mathrm{CD})$ by crystalization-induced self-assembly. The delivery system exhibited a sustained drug release, regardless of hydrophilic drug DOX or hydrophobic drug 5-FU. In cell viability tests, DOX and 5-FU exhibited a synergetic anti-tumor effect.

Mohtar et al. has investigated complexation of fisetin, a natural flavonoid, with three types of cyclodextrins to improve its solubility [6]. Sulfobutylether- $\beta$-cyclodextrin (SBE- $\beta$-CD) showed the highest complexation efficiency while maintaining the in vitro antioxidant activity of fisetin. This formulation also showed an $\mathrm{EC}_{50}$ value equivalent to fisetin alone in the $\mathrm{A} 549$ cell line. In conclusion, an inhalable dry powder containing fisetin-SBE- $\beta$-CD complex was successfully engineered with an improved aqueous solubility of fisetin.

Supramolecular cyclodextrin (CD) hydrogels have occupied an important position in developing the materials for biomedical application. The work by Sing and his co-workers attempted to improve the release profile of ciprofloxacin by designing the $\beta$-cyclodextrin-containing drug delivery system through network formation and supramolecular interactions [7]. The release of drug from $\beta$-CD containing hydrogels was slower and less as compared to the hydrogels without $\beta$-CD. These hydrogels have been found haemocompatible, mucoadhesive, and antioxidant in nature.

A novel drug delivery system was developed through the modification of MSNs (mesoporous silica nanoparticles) with $\beta$-CD [8]. The experiment results demonstrated that the cytotoxicity of this drug delivery system was very low, and 
the doxorubicin loading ratio was $\sim 27.36 \%$. The behavior of drug release was $\mathrm{pH}$ dependent which can potentially be used as the drug controlling releasing in cancer cell.

Brudno et al. studied the development of a drug delivery system which permits refilling of a drug delivery device in vivo in a minimally invasive manner, by modifying the drug delivery device with molecular targets capable of recognizing and binding drug refills circulating in the body [9]. The drug delivery system features a dual functionality drug refill, which not only permits a direct targeted delivery of a pharmaceutical compound from the drug refill to the drug delivery device, but also masks the potential toxicity of a pharmaceutical compound, such as a chemotherapeutic, until the pharmaceutical compound is delivered to the drug delivery device. The pharmaceutical compound will only be unmasked upon delivery into the drug delivery device where the target is separated from the pharmaceutical compound, thus eliminating any side effects or toxicity associated with the pharmaceutical compound at any undesired sites.

Paczkowska prepared an inclusion complex of $\beta$-cyclodextrin and meropenem [10]. An analysis of changes in the stability of meropenem after complexation showed that the complex may serve as a valuable delivery system significantly contributing to enhanced meropenem stability in aqueous solutions and in the solid phase. Due to a sustained transfer of meropenem from the cavity of the cyclodextrin it was possible to maintain a constant desired meropenem concentration over a period of $20 \mathrm{~h}$, as confirmed by a release study.

Erlotinib (ERL) is a drug used in epidermoid carcinoma treatment. One of the ERL drawbacks is low water solubility, which limits its use in the development of safer and effective formulations. The study by Gontijo et al. used the strategy of inclusion complexation with hydroxypropyl- $\beta$-cyclodextrin (HP- $\beta$-CD) to increase the ERL water solubility [11]. Despite free ERL higher cytotoxicity, higher values were associated with the complex compared with free ERL $(37.5 \mu \mathrm{M})$ and the complex was more cytotoxic to A431 human epidermoid carcinoma cell than to osteoblasts (non-cancerous cells). In addition, the inclusion complex exhibited antiangiogenic activity without affecting the activation and recruitment of neutrophils and macrophage. Overall, these results suggest that the ERL: HP- $\beta$ $\mathrm{CD}$ inclusion complex could be a promising approach for developing safe and effective ERL formulation by different routes of administration.

A drug delivery system that allows sustained drug release could reduce the medical burden and costs associated with medication nonadherence in individuals infected with human immunodeficiency virus (HIV). We recently demonstrated that a supramolecular assembly composed of hyaluronic acid, sulfobutylether- $\beta$-cyclodextrin, and poly-L-lysine can encapsulate the anti-HIV drugs zidovudine and lamivudine. The supramolecular assembly showed a potent antiviral activity in vitro with sustained drug release property [12].

To achieve cancer targeting drug delivery in our proposed work, folic acid (FA) will be used as a cancer targeting ligand because FA is a prominent targeting moiety capable of specific interaction with a range of tumor cells expressing 
the folate receptor (FR). FR binds to folate with a high affinity (Kd: 1029210210 $\mathrm{M})$ and is attached to the plasma membrane through a glycosylphosphatidylinositol (GPI) anchor. FR is overexpressed in many human tumor cells, including malignancies of the ovary, brain, kidney, breast, myeloid cells and lung, and its expression is low in normal tissues. The higher levels of FR expressed on tumor cells facilitates efficient uptake of the FA essential for DNA synthesis and seems to aid in aggressive tumor growth. In patients diagnosed with cancer, the overexpression of FR isoform a (FR-a) correlates with a higher histological grade and more advanced stage of the disease. Therefore, FR is one of the strongest candidates, both as an attractive marker and a target molecule for diagnosis and therapy of cancer [13] [14] [15]. Therefore, we plan to synthesize compounds containing both folate receptor and $\beta$-cyclodextrin using phenanthroline as a linker.

\section{General Method and Procedures: Materials and Methods}

\subsection{Materials}

$\beta$-cyclodextrin, $p$-toluenesulfonylchloride, ethylenediamine, folic acid, and 2, 9-dimethyl-1,10-phenanthroline hemi-hydrate were purchased from Sigma-Aldrich Chemical Co. (St. Louis, MO, USA). HPLC grade solvents were used in all the reactions without any further purification.

\subsection{Methods}

To obtain NMR spectra, all compounds were dissolved in DMSO-d6 or $\mathrm{D}_{2} 0$ and recorded on a Bruker Ascend $400 \mathrm{MHz}$ NMR spectrometer using TMS as an internal standard. All infra-red (IR) data were recorded $\left(v_{\max }\right.$ in $\left.\mathrm{cm}^{-1}\right)$ on Smart iRT purchased from Thermo Scientific.

\section{Synthesis}

Over the past several years our laboratory has been involved in the synthesis of Schiff bases containing phenanthroline and O,S,N-containing amines to explore their antibacterial properties [16] [17] [18]. Several compounds were successfully synthesized and their antibacterial properties have been studied with promising results. Our current research involves the utilization of phenanthroline to link $\beta$-cyclodextrin as drug delivery moiety and folic acid as cancer targeting ligand. This paper discusses the synthesis of folate appended $\beta$-cyclodextrin using phenanthroline as the linker. Systematic discussions about the synthesis of this target molecule are discussed below. Following retrosynthetic pathway (Figure 1) has been considered in order to achieve our synthetic goal. Target compound NKS-1 could be synthesized by Schiff base reaction of the amine $\underline{4}$ with the aldehyde $\underline{3}$ followed by reacting the alcohol group of $\underline{3}$ with folic acid chloride. Compound $\underline{3}$ can be obtained by oxidation of one aldehyde group with $\mathrm{MnO}_{2}$. Di-aldehydes are easily prepared from the corresponding dimethyl compound 1 . Compound $\underline{4}$ can be synthesized from the corresponding tosylated cyclodextrin $\underline{7}$ and ethylenediamine $\underline{6}$. 


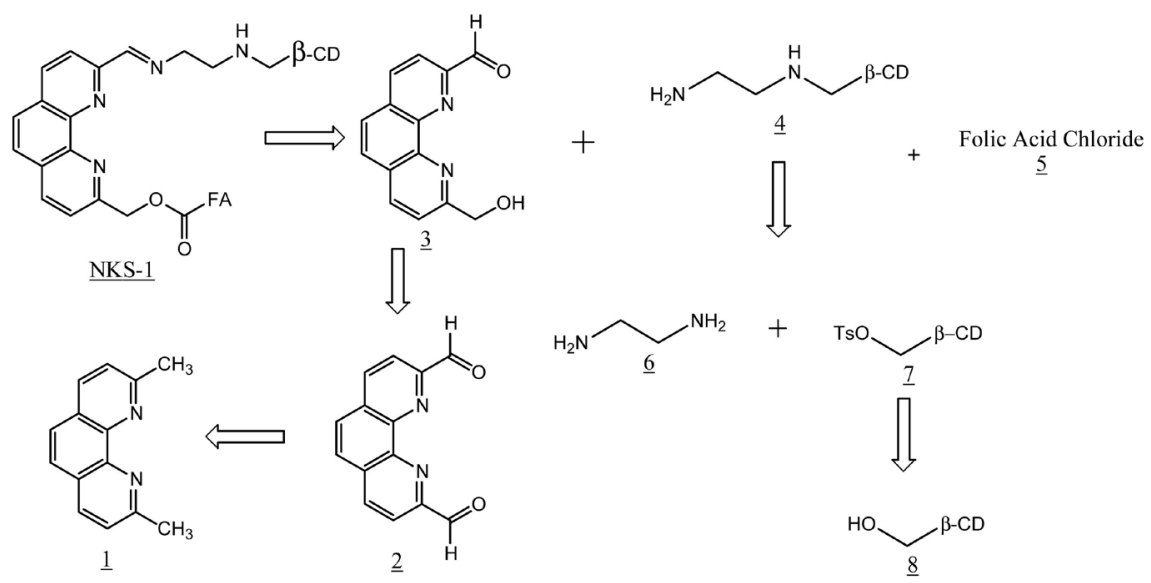

Figure 1. Retrosynthetic ananlysis of target compound NKS-1.

\subsection{Synthesis of 1,10-Phenanthroline-2,9-Di- Carboxaldehyde from 2,9-Dimethyl-1,10- Phenanthrolinehemi-Hydrate}

This compound has been synthesized using literature procedure [19] [20] [21]. (Y: 70\%). IR: $v\left(\mathrm{~cm}^{-1}\right) 3041\left(\mathrm{CH}\right.$ aromatic), $1677(\mathrm{C}=\mathrm{O}), 1580(\mathrm{C}=\mathrm{N}) .{ }^{1} \mathrm{HNMR}$ $\left(\delta\right.$, DMSO- $\left._{6}\right): 10.36(\mathrm{~s}, 2 \mathrm{H}, \mathrm{CHO}), 8.9(\mathrm{~d}, 2 \mathrm{H}, \mathrm{Ar}-\mathrm{H}), 8.36(\mathrm{~m}, 4 \mathrm{H}, \mathrm{Ar}-\mathrm{H})$. ${ }^{13} \mathrm{CNMR}\left(\delta\right.$, DMSO-d $\left.{ }_{6}\right): 194.13,152.68,145.77,138.86,131.95,129.76,120.67$ (Scheme 1).

\subsection{Synthesis of 1,10-Phenanthroline-2,9-Di-Hydroxymethyl from 1,10-Phenanthroline-2,9-Di-Carboxaldehyde}

1,10-phenanthroline-2,9-dicarboxaldehyde $2(1.0 \mathrm{~g}, 0.0042 \mathrm{~mol})$ was dissolved in $50 \mathrm{ml}$ ethanol keeping the beaker on ice. $\mathrm{NaBH}_{4}(0.320 \mathrm{~g}, 0.0084 \mathrm{~mol})$ was added to the cooled solution and was warmed with continuous stirring for 5 minutes followed by the addition of water $(10 \mathrm{~mL})$. Afterwards, it was again heated to boiling point until clear solution was formed. Reaction mixture was kept in room temperature for $3 \mathrm{~h}$ and then filtered. The filtrate was evaporated by rotary evaporator to get solid product 9 (Y: 75\%). IR: $v\left(\mathrm{~cm}^{-1}\right) 3228(\mathrm{OH})$, 3021 ( $\mathrm{CH}$ aromatic), 2854 ( $\mathrm{CH}$ aliphatic), $1573(\mathrm{C}=\mathrm{N}) .{ }^{1} \mathrm{HNMR}\left(\delta\right.$, DMSO-d $\left.{ }_{6}\right)$ : 8.9 (d, 2H, Ar-H), 7.93 (m, 4H, Ar-H), 5.69 (s, 2H, OH), 4.89 (s, 4H, $\mathrm{CH}_{2}$ ). ${ }^{13} \mathrm{CNMR}\left(\delta\right.$, DMSO-d $\left.\mathrm{d}_{6}\right): 162.62,144.14,137.72,127.97,126.43,121.29,65.07$ (Scheme 2).

\subsection{Synthesis of 1,10-Phenanthroline-9-Hydroxymethyl-2- Carboxaldehyde from 1,10-Phenanthroline-2, 9-Di-Hydroxymethyl}

1,10-phenanthroline-2,9-di-hydroxymethyl $9(0.800 \mathrm{~g}, 0.0034 \mathrm{~mol})$ and $\mathrm{MnO}_{2}$ (19.12 g, $0.2199 \mathrm{~mol})$ were dissolved in $250 \mathrm{ml}$ of chloroform. The mixture was refluxed for $48 \mathrm{~h}$ followed by filtration while hot using celite pad. The filtrate was then evaporated using rotary evaporator to obtain the product 3 [22]. The crude product was purified by flash chromatography (Y: 30\%). IR: $v\left(\mathrm{~cm}^{-1}\right), 3372$ 
$(\mathrm{OH}), 2820\left(\mathrm{CH}\right.$ aliphatic), $\left.1674(\mathrm{C}=\mathrm{O}) .{ }^{1} \mathrm{HNMR}\left(\delta, \mathrm{DMSO}^{\mathrm{d}}\right)_{6}\right) 10.3(\mathrm{~s}, 1 \mathrm{H}$, $\mathrm{CHO})$, 7.9-8.7 $(6 \mathrm{H}, \mathrm{Ar}-\mathrm{H}), 5.7(\mathrm{~s}, 1 \mathrm{H}, \mathrm{OH}), 4.90\left(\mathrm{~s}, 2 \mathrm{H}, \mathrm{CH}_{2}\right) .{ }^{13} \mathrm{CNMR}(\delta$, DMSO-d $\left.{ }_{6}\right): 194.42,163.64,152.04,145.63,144.76,138.37,137.50,131.40$, $129.95,128.21,125.88,121.24,119.79,64.61$. NMR spectra are shown in Appendix (Scheme 3).

\subsection{Synthesis of Folic Acid Chloride from Folic Acid}

Folic acid ( $0.500 \mathrm{~g}, 0.0001 \mathrm{~mole})$ was dissolved in $15 \mathrm{ml}$ of thionyl chloride and stirred for $2 \mathrm{hr}$. The reaction mixture was then evaporated and washed with acetone to obtain folic acid chloride 5 (Y: 70\%). IR: $v\left(\mathrm{~cm}^{-1}\right) 3145(\mathrm{OH}), 2948(\mathrm{CH}$ aliphatic), $1687(\mathrm{C}=\mathrm{O}), 1562\left(\mathrm{C}=\mathrm{C}\right.$ aromatic). ${ }^{1} \mathrm{HNMR}\left(\delta, \mathrm{DMSO}_{\mathrm{d}}\right): 8.73(\mathrm{~s}$, $1 \mathrm{H}), 8.15(\mathrm{~d}, 1 \mathrm{H}), 7.87(\mathrm{t}, 1 \mathrm{H}), 7.66(\mathrm{~d}, 2 \mathrm{H}), 6.65(\mathrm{~d}, 2 \mathrm{H}), 4.55(\mathrm{~d}, 2 \mathrm{H}), 4.33(\mathrm{~m}$, $1 \mathrm{H}), 2.31(\mathrm{t}, 2 \mathrm{H}), 2.05(\mathrm{t}, 1 \mathrm{H}), 1.90(\mathrm{t}, 1 \mathrm{H}) .{ }^{13} \mathrm{CNMR}\left(\delta, \mathrm{DMSO}-\mathrm{d}_{6}\right): 174.44$, $174.18,166.82,159.72,153.18,151.73,151.06,148.31,129.43,128.50,121.86$, $111.75,52.15,46.22,30.89,26.44$ (Scheme 4).

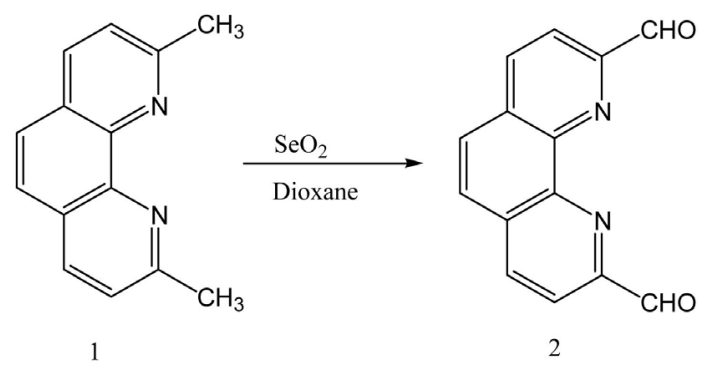

Scheme 1. Synthesis of 1, 10-phenanthroline-2,9-di-carboxaldehydefrom 2,9-dimethyl-1, 10-phenanthrolinehemi-hydrate.

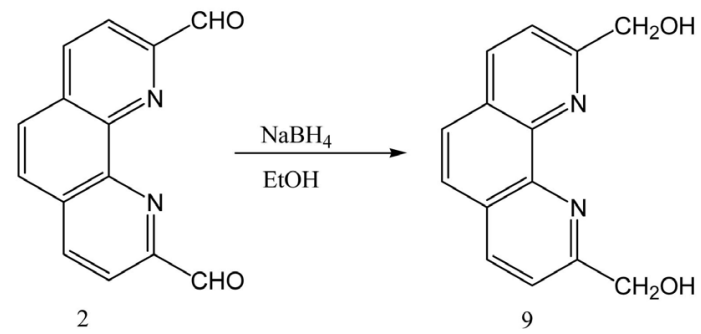

Scheme 2. Synthesis of 1,10-phenanthroline-2,9-di-hydroxymethyl from 1,10-phenanthroline-2,9-di-carboxaldehyde.

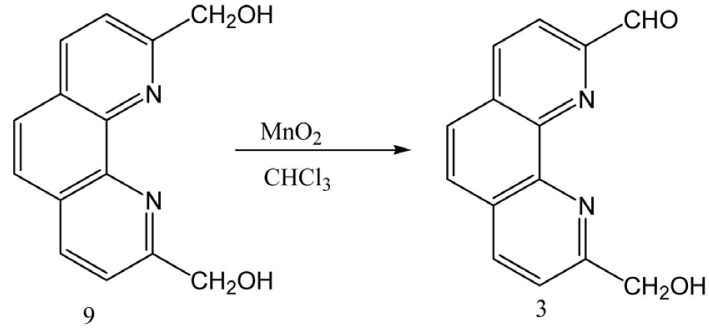

Scheme 3. Synthesis of 1,10-phenanthroline-9-hydroxymethyl-2-carboxaldehyde from 1, 10-phenanthroline-2,9-di-hydroxymethyl. 


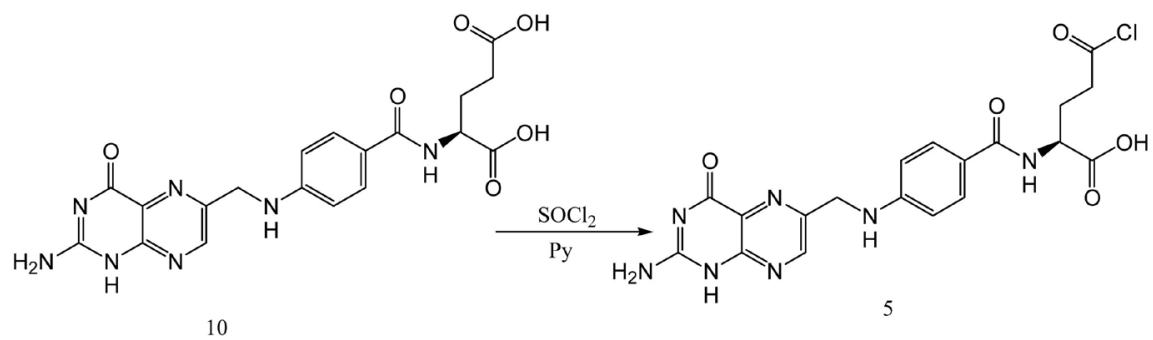

Scheme 4. Synthesis of folic acid chloride from folic acid.

\subsection{Synthesis of Mono-6-(p-Tosylsulfonyl)-6-Deoxy- $\beta$ - Cyclodextrin (6-OTs- $\beta$-CD)}

Literature procedure was followed [23]. $\beta$-cyclodextrin $(30.0 \mathrm{~g}, 0.026 \mathrm{~mol})$ was dissolved in $250 \mathrm{ml}$ water at room temperature and $10 \mathrm{ml} \mathrm{NaOH}(8.25 \mathrm{M})$ was added dropwise over $5 \mathrm{~min}$. A solution of p-toluenesulfonyl chloride $(7.5 \mathrm{~g}$, $0.039 \mathrm{~mol}$ ) dissolved in $15 \mathrm{ml}$ of acetonitrile was added dropwise over $6 \mathrm{~min}$ forming a white precipitate. The precipitate was removed by filtration after stirring for $2 \mathrm{~h}$ at room temperature. The filtrate was acidified to about $\mathrm{pH} 8-9$ with $1 \mathrm{M} \mathrm{HCl}$ and kept it in a refrigerator at $4^{\circ} \mathrm{C}$ for overnight. The resulting white precipitate was recovered by filtration. The solid product was recrystallized 3 times with water as the solvent. Finally, the product 5 was dried for $6 \mathrm{~h}$ at $60^{\circ} \mathrm{C}$ (Y: 9\%) [8]. IR: $v\left(\mathrm{~cm}^{-1}\right) 3281(\mathrm{OH}), 1625\left(\mathrm{Ph}_{-} \mathrm{SO}_{2}-\right), 812$ (Ph-SO $\left.{ }_{2}-\mathrm{O}-\mathrm{R}\right)$. ${ }^{1} \mathrm{HNMR}\left(\delta\right.$, DMSO-d $\left.\mathrm{d}_{6}\right): 7.77(\mathrm{~d}, 2 \mathrm{H}), 7.44(\mathrm{~d}, 2 \mathrm{H}), 5.73(\mathrm{bs}, 14 \mathrm{H}), 4.83(\mathrm{~s}, 6 \mathrm{H})$, 4.77 (s, 1H), 4.48 (bs, 6H), 4.35 (d, 1H), 4.19 (dd, 1H), 3.17 - 3.78 (m, 40H), 2.43 $(\mathrm{s}, 3 \mathrm{H})$. For simplicity, an abbreviated structure of $\beta$-cyclodextrin is shown below: (Scheme 5).

\subsection{Synthesis of Mono-[6-(Ethylenediamino)-6-Deoxy- $\beta$-Cyclodextrin (EDA- $\beta$-CD)}

Literature procedure was followed [24]. The dried mono-6-(p-tosylsulfonyl)-6deoxy- $\beta$-cyclodextrin 7 ( $3.0 \mathrm{~g}, 0.0024 \mathrm{~m} \mathrm{~mol})$ was dissolved in $20 \mathrm{ml}$ of anhydrous ethylenediamine and then stirred at $80^{\circ} \mathrm{C}$ for $4 \mathrm{~h}$ under $\mathrm{N}_{2}$. After the reaction was complete, the mixture was cooled to room temperature. A large amount of cold acetone $(\sim 350 \mathrm{ml})$ was added, and the precipitate was collected by filtration. To remove unreacted EDA in the precipitate, it was first re-dissolved in water, and precipitated by addition of cold acetone. Then product was recovered by centrifuging at $10,000 \mathrm{rpm}, 4^{\circ} \mathrm{C}$ for $10 \mathrm{~min}$. The same purification procedure was repeated for 4 times. The final precipitate was dried under vacuum to afford white solid product 4 [8]. $(\mathrm{Y}=80 \%)$. IR: $v\left(\mathrm{~cm}^{-1}\right) 3291(\mathrm{OH}), 730 \& 750$ (primary amine). ${ }^{1} \mathrm{NMR}\left(\delta, \mathrm{D}_{2} \mathrm{O}\right): 4.98(\mathrm{~s}, 7 \mathrm{H}), 3.86(\mathrm{t}, 7 \mathrm{H}), 3.78(\mathrm{bs}, 14 \mathrm{H}), 3.55$ (dd, 6H), $3.49(\mathrm{t}, 6 \mathrm{H}), 3.37(\mathrm{t}, 1 \mathrm{H}), 2.95(\mathrm{~d}, 1 \mathrm{H}), 2.59$ - $2.78(\mathrm{~m}, 4 \mathrm{H})$ (Scheme 6).

The - $\mathrm{CHO}$ and $-\mathrm{OH}$ groups at the 2-and 9-positions of phenanthroline were the key functional groups that were considered in order to attach $\beta$-CD and folate moiety. While synthesis of this key intermediate involves several steps, we found furfuraldehyde $\underline{11}$ which contains the same functional group and was 


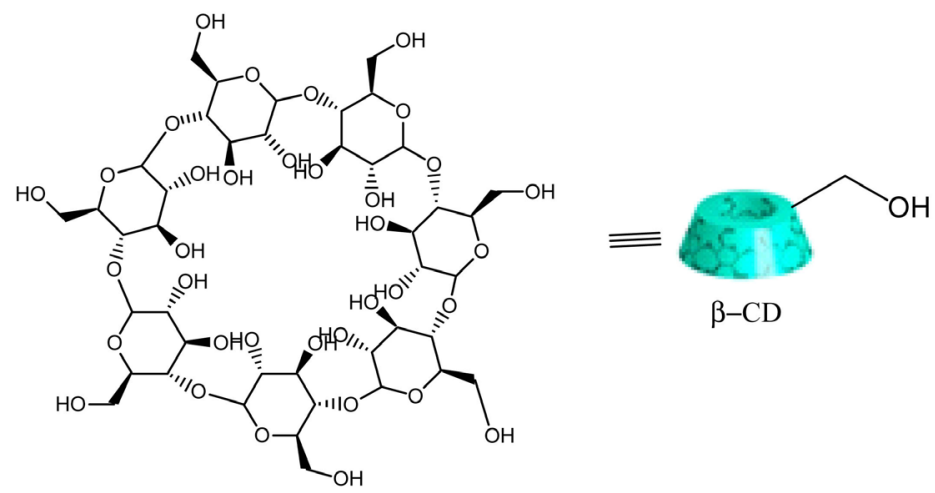

$\beta$-Cyclodextrin



Scheme 5. Synthesisofmono-6-(p-tosylsulfonyl)-6-deoxy- $\beta$-cyclodextrin) (6-OTs- $\beta$-CD).

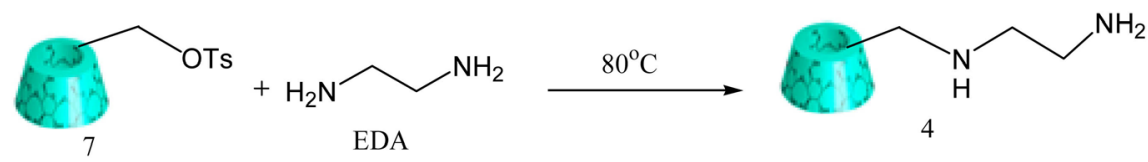

Scheme 6. Synthesis of mono-[6-(ethylenediamino)-6-deoxy- $\beta$-cyclodextrin (EDA- $\beta$-CD).

commercially available. Therefore, we decided to attach $\beta$-CD and folate moiety using this commercially available intermediate.

\subsection{Synthesis of Mono-[6-(5-Hydroxymethyl-2- Furanylideneamino)-Ethyl]Amino]-6-Deoxy]- $\beta$-Cyclodextrin (Schiff Base)}

5-(hydroxymethyl-2-furaldehyde $11(0.039 \mathrm{~g}, 0.0003 \mathrm{~mol})$ and mono-[6-(ethylenediamino)-6-deoxy- $\beta$-cyclodextrin 4 (0.200 g, $0.00017 \mathrm{~mol})$ was added in ethanol solvent $(20 \mathrm{ml})$, followed by the addition of glacial acidic acid (5 drops). The reaction mixture was refluxed for $3 \mathrm{~h}$ and stirred for another $3 \mathrm{~h}$ at room temperature. Afterward, solvent was evaporated by rotary evaporator. The solid crude product was dissolved in $150 \mathrm{ml}$ of acetone with stirring for $1 \mathrm{~h}$, and then filtered. To the solid, acetone was added again and the procedure was repeated two times to eliminate unreacted aldehyde and glacialacetic acid. Finally, the resulting solid was dissolved in ethanol, filtered and evaporated by rotary evaporator to obtain a solid yellow product $12(\mathrm{Y}: 45 \%)$ [24]. IR: $v\left(\mathrm{~cm}^{-1}\right) 3291(\mathrm{OH})$, 2906 (CH aliphatic), $1635(\mathrm{C}=\mathrm{N}) .{ }^{1} \mathrm{HNMR}\left(\delta, \mathrm{DMSO}_{6}\right): 8.1(\mathrm{~s}, 1 \mathrm{H},-\mathrm{CH}=\mathrm{N}-)$, $6.8(\mathrm{~d}, 1 \mathrm{H}, \mathrm{Ar}-\mathrm{H}), 6.4(\mathrm{~d}, 1 \mathrm{H}, \mathrm{Ar}-\mathrm{H}), 5.7(\mathrm{~m}, 14 \mathrm{H}), 4.83$ (bs, 7H), $4.46(\mathrm{~d}, 7 \mathrm{H})$, 3.26 - $3.74(\mathrm{~m}, 42 \mathrm{H}), 2.65$ - 3.17 (m, 4H) (Scheme 7). 


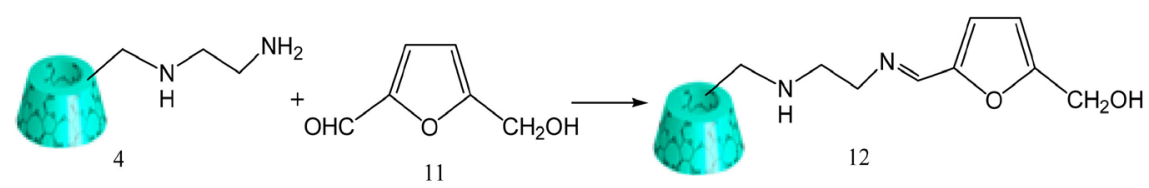

Scheme 7. Synthesis of mono-[6-(5-hydroxymethyl-2-furanylideneamino)-ethyl]amino]6-deoxy]- $\beta$-cyclodextrin (Schiff Base).

\subsection{Synthesis of Folate-Appended $\beta$-Cyclodextrin Using 5 (Hydroxymethyl) Furfural (NKS-2)}

Mono-[6-[5-hydroxymethyl-2-furanylideneamino)-ethyl]amino]-6-deoxy]- $\beta$ cyclodextrin $12(0.100 \mathrm{~g}, 0.000078 \mathrm{~mol})$ was dissolved in $15 \mathrm{ml}$ of chloroformwith folic acid chloride $5(0.039 \mathrm{~g}, 0.000078 \mathrm{~mol})$ and 4 drops of trimethylamine. Then the reaction mixture was stirred at $50^{\circ} \mathrm{C}$ for $2 \mathrm{~h}$. Finally, solvent was evaporated to obtain solid yellow product NKS-2 (Y: 60\%). IR: $v\left(\mathrm{~cm}^{-1}\right): 3283(\mathrm{OH})$, $1591(\mathrm{C}=\mathrm{N}), 1630(\mathrm{CO}) .{ }^{1} \mathrm{HNMR}\left(\delta\right.$, DMSO-d $\left.\mathrm{d}_{6}\right): 6.39-8.63(\mathrm{bs} 10 \mathrm{H}), 5.70(\mathrm{~m}$, $14 \mathrm{H}), 4.85(\mathrm{bs}, 7 \mathrm{H}), 4.46(\mathrm{~d}, 6 \mathrm{H}), 4.42(\mathrm{~s}, 1 \mathrm{H}), 4.27(\mathrm{~m}, 2 \mathrm{H}), 3.19-3.76(\mathrm{~m}$, $42 \mathrm{H}), 2.65$ (m, 4H), $2.30(\mathrm{~m}, 2 \mathrm{H}), 2.20(\mathrm{~m}, 2 \mathrm{H})$ (Scheme 8).

After successful completion of the synthesis of folate appended $\beta$-cyclodextrin using furfuraldehydeas the linker, we attempted the synthesis of NSK-1 using phenanthroline as the linker. Similar procedure was used.

\subsection{Synthesis of Mono-[6-[1, 10-Phenanthroline- 9-Hydroxymethyl-2-Carboxaldehydelideneamino)-Ethyl] Amino]-6-Deoxy]- $\beta$-Cyclodextrin (Schiff Base)}

1, 10-phenanthroline-9-hydroxymethyl-2-carboxaldehyde 3 (0.072 g, 0.0003 mol) and mono-[6-(ethylenediamino)-6-deoxy- $\beta$-cyclodextrin 4 (0.200 g, $0.00017 \mathrm{~mol})$ was added in ethanol solvent $(20 \mathrm{ml})$. Then glacial acidic acid $(5$ drops) was added into the solution. The reaction mixture was refluxed for $3 \mathrm{~h}$, and stirred for another $3 \mathrm{~h}$ at room temperature. Afterwards, solvent was evaporated by rotary evaporator. The solid crude product was dissolved in $150 \mathrm{ml}$ of acetone and stirred for $1 \mathrm{~h}$ and filtered. This procedure was repeated two times to eliminate unreacted aldehyde and glacial acetic acid. Finally, the resulting solid was dried to yield a solid yellow product 13 (Y: 40\%) [24]. IR: $v\left(\mathrm{~cm}^{-1}\right) 3271$ $(\mathrm{OH}), 2937$ ( $\mathrm{CH}$ aliphatic), $1687(\mathrm{C}=\mathrm{N}) .{ }^{1} \mathrm{HNMR}\left(\boldsymbol{\delta}, \mathrm{DMSO}_{6}\right)$ : 7.7-8.6 (bs, $7 \mathrm{H}), 5.7(\mathrm{~m}, 14 \mathrm{H}), 4.80(\mathrm{bs}, 7 \mathrm{H}), 4.40(\mathrm{~d}, 7 \mathrm{H}), 3.16-3.72(\mathrm{~m}, 42 \mathrm{H}), 2.65-3.17$ $(\mathrm{m}, 4 \mathrm{H})$ (Scheme 9).

\subsection{Synthesis of Folate-Appended $\beta$-Cyclodextrin Using 1,0-Phenanthroline}

Mono-[6-[1,10-phenanthroline-9-hydroxymethyl-2-carboxaldehydelideneamino)ethyl]amino]-6-deoxy]- $\beta$-cyclodextrin $(0.100 \mathrm{~g}, 0.000071 \mathrm{~mol})$ was dissolved in $15 \mathrm{ml}$ of chloroform with folic acid $(0.036 \mathrm{~g}, 0.000071 \mathrm{~mol})$ and 4 drops of triethylamine. Then the reaction mixture was stirred at $50^{\circ} \mathrm{C}$ for $2 \mathrm{~h}$. Finally, solvent was evaporated to yield solid yellow product (Y: 48\%).IR: $v\left(\mathrm{~cm}^{-1}\right)$ : $3375(\mathrm{OH})$, 
$1677(\mathrm{CO}), 1573(\mathrm{C}=\mathrm{N}) .{ }^{1} \mathrm{HNMR}\left(\delta\right.$, DMSO-d $\left.\mathrm{d}_{6}\right): 6.58-8.67(\mathrm{bs}, 10 \mathrm{H}), 5.70(\mathrm{~m}$, $14 \mathrm{H}), 4.82(\mathrm{bs}, 7 \mathrm{H}), 4.47(\mathrm{~d}, 6 \mathrm{H}), 4.44(\mathrm{~s}, 1 \mathrm{H}), 4.30(\mathrm{~m}, 2 \mathrm{H}), 3.11-3.72(\mathrm{~m}$, $42 \mathrm{H}), 2.66(\mathrm{~m}, 4 \mathrm{H}), 2.32(\mathrm{~m}, 2 \mathrm{H}), 2.17(\mathrm{~m}, 2 \mathrm{H})$ (Scheme 10).

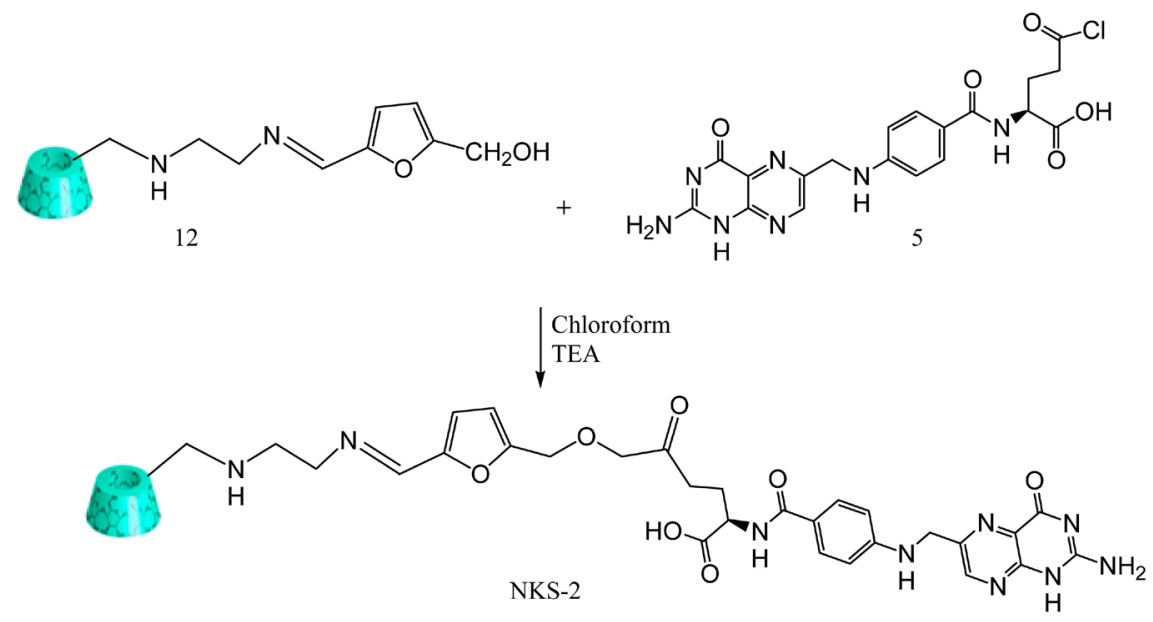

Scheme 8. Synthesis of Folate-Appended $\beta$-Cyclodextrin using 5 (hydroxymethyl) furfural.

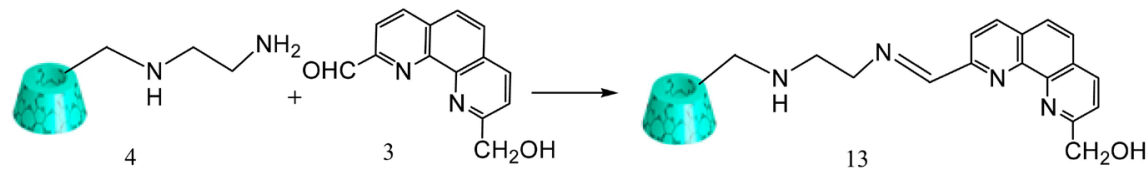

Scheme 9. Synthesis of Mono-[6-(1,10-Phenanthroline-9-hydroxymethyl-2-Carboxaldehydelideneamino)-ethyl]amino]-6-deoxy]- $\beta$-cyclodextrin ( Schiff Base).

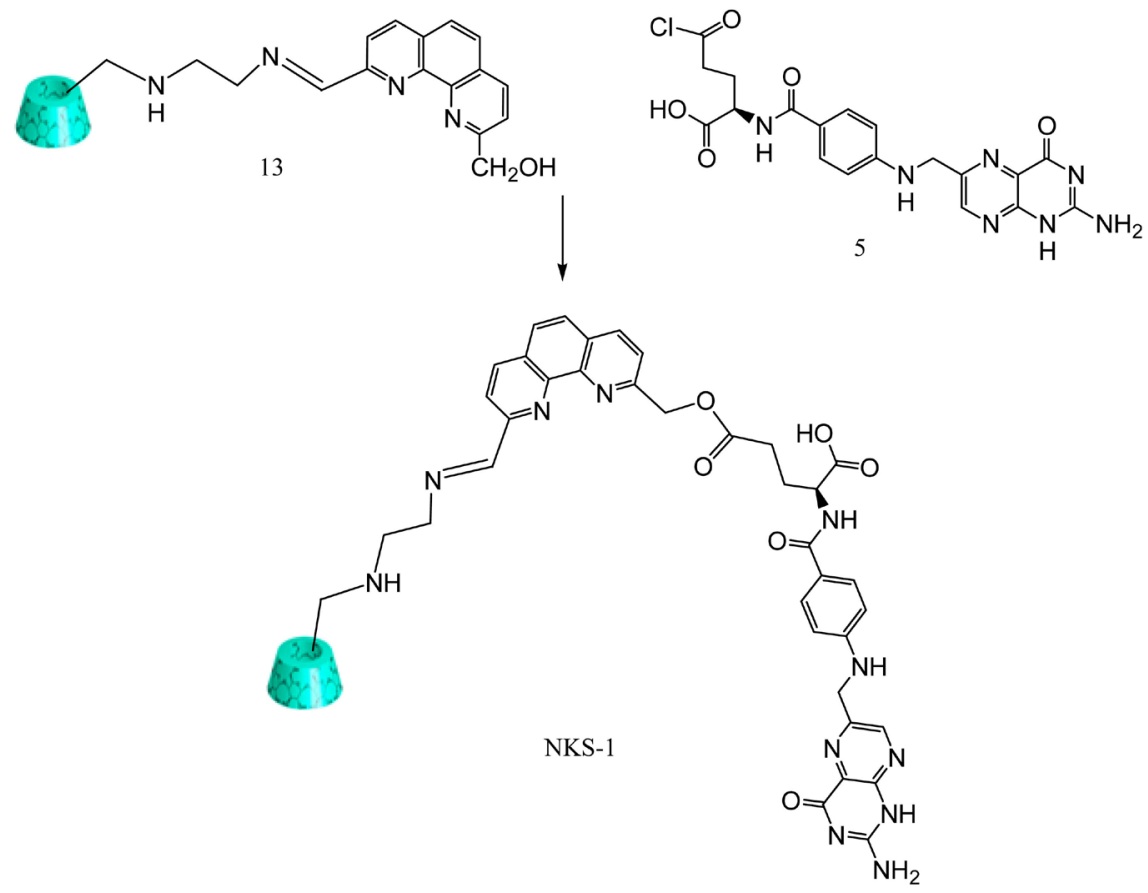

Scheme 10. Synthesis of Folate-Appended $\beta$-Cyclodextrin using 1,0-phenanthroline. 


\section{Conclusion}

Two folate-appended $\beta$-cyclodextrins have been successfully synthesized and characterized. Folate appended $\beta$-cyclodextrins as well their precursors will be tested for anticancer activities. The efficiencies of drug delivery will also be explored with cyclodextrin containing products.

\section{Conflicts of Interest}

The authors declare no conflicts of interest regarding the publication of this paper.

\section{References}

[1] Davis, M.E. and Brewster, M.E. (2004) Cyclodextrin-Based Pharmaceutics: Past, Present and Future. Nature Reviews Drug Discovery, 3, 1023-1035. https://doi.org/10.1038/nrd1576

[2] Yakavets, I., Lassalle, H.-P., Scheglmann, D., Wiehe, A., Zorin, V. and Bezdetnaya, L. (2018) Temoporfin-in-Cyclodextrin-in-Liposome-A New Approach for Anticancer Drug Delivery: The Optimization of Composition. Nanomaterials, 8, 847/1$847 / 15$.

[3] Hyun, H., Lee, S., Lim, W., Jo, D., Jung, J.S., Jo, G., Kim, S.Y., Lee, D.-W., Um, S., Yang, D.H., et al. (2019) Engineered Beta-Cyclodextrin-Based Carrier for Targeted Doxorubicin Delivery in Breast Cancer Therapy in Vivo. Journal of Industrial and Engineering Chemistry (Amsterdam, Netherlands), 70, 145-151. https://doi.org/10.1016/j.jiec.2018.09.052

[4] Khalid, Q., Ahmad, M. and Usman Minhas, M. (2018) Hydroxypropyl- $\beta$-Cyclodextrin Hybrid Nanogels as Nano-Drug Delivery Carriers to Enhance the Solubility of Dexibuprofen: Characterization, in Vitro Release, and Acute Oral Toxicity Studies. Advances in Polymer Technology, 37, 2171-2185.

https://doi.org/10.1002/adv.21876

[5] Kong, L., Zhang, F., Xing, P.Y., Chu, X.X. and Hao, A.Y. (2017) A Binary Solvent Gel as Drug Delivery Carrier. Colloids and Surfaces, A: Physicochemical and Engineering Aspects, 522, 577-584. https://doi.org/10.1016/j.colsurfa.2017.03.016

[6] Mohtar, N., Taylor, K.M.G., Sheikh, K. and Somavarapu, S. (2017) Design and Development of Dry Powder Sulfobutylether- $\beta$-Cyclodextrin Complex for Pulmonary Delivery of Fisetin. European Journal of Pharmaceutics and Biopharmaceutics, 113, 1-10. https://doi.org/10.1016/j.ejpb.2016.11.036

[7] Singh, B., Dhiman, A., Rajneesh and Kumar, A. (2016) Slow Release of Ciprofloxacin from $\beta$-Cyclodextrin Containing Drug Delivery System through Network Formation and Supramolecular Interactions. International Journal of Biological Macromolecules, 92, 390-400. https://doi.org/10.1016/j.ijbiomac.2016.07.060

[8] Wei, G.C., Li, J.L., Yan, M.M. and Wang, C.H. (2016) Surface Modification of MSNs with $\beta$-CD and Use as a Drug Delivery System. Materials Technology ( $A b$ ingdon, United Kingdom), 31, 482-486.

[9] Brudno, Y., Kearney, C.J., Silva, E., Aizenberg, M., Kwee, B., Desai, R., Joshi, N.S. and Mooney, D.J. (2016) Refillable Drug Delivery Devices and Methods of Use Thereof. US Pat. Appl. Publ., US 20160114046 A1 20160428.

[10] Paczkowska, M., Mizera, M., Szymanowska-Powalowska, D., Lewandowska, K., Blaszczak, W., Goscianska, J., Pietrzak, R. and Cielecka-Piontek, J. (2016) $\beta$-Cyclo- 
dextrin Complexation as an Effective Drug Delivery System for Meropenem. European Journal of Pharmaceutics and Biopharmaceutics, 99, 24-34. https://doi.org/10.1016/j.ejpb.2015.10.013

[11] Gontijo, S.M.L., Guimaraes, P.P.G., Viana, C.T.R., Denadai, A.M.L., Gomes, A.D.M., Campos, P.P., Andrade, S.P., Sinisterra, R.D. and Cortes, M.E. (2015) Erlotinib/Hydroxypropyl- $\beta$-Cyclodextrin Inclusion Complex: Characterization and in Vitro and in Vivo Evaluation. Journal of Inclusion Phenomena and Macrocyclic Chemistry, 83, 267-279. https://doi.org/10.1007/s10847-015-0562-3

[12] Song, B., Puskás, I., Szente, L. and Hildreth, J.E.K. (2016) Hyaluronic Acid-Based Biocompatible Supramolecular Assembly for Sustained Release of Antiretroviral Drug. Journal of Pharmaceutical Sciences, 105, 2760-2769.

https://doi.org/10.1016/j.xphs.2016.01.023

[13] Sambamoorthy, U., Venkataraju, M.P., Manjappa, A.S. and Rao, M.E.B. (2019) Gemcitabine-Loaded Folic acid Tagged Liposomes: Improved Pharmacokinetic and Biodistribution Profile. Current Drug Delivery, 16, 111-122

[14] Sun, Y., Shi, C., Yang, J., Zhong, S., Li, Z., Xu, L., Zhao, S., Gao, Y. and Cui, X. (2018) Fabrication of Folic Acid Decorated Reductive-Responsive Starch-Based Microcapsules for Targeted Drug Delivery via Sonochemical Method. Carbohydrate Polymers, 15, 508-515. https://doi.org/10.1016/j.carbpol.2018.08.036

[15] Qiu, L., Dong, C. and Kan, X. (2018) Lymphoma-Targeted Treatment Using a Folic Acid-Decorated Vincristine-Loaded Drug Delivery System. Drug Design, Development and Therapy, 12, 863-872. https://doi.org/10.2147/DDDT.S152420

[16] Jaman, Z., Karim, M.R., Siddiquee, T.A., Mirza, A.H. and Ali, M.A. (2013) Synthesis of 5-Substituted 2, 9-Dimethyl-1, 10-Phenanthroline Dialdehydes and Their Schiff bases with Sulfur-Containing Amines. International Journal of Organic Chemistry, 3, 214-219. https://doi.org/10.4236/ijoc.2013.33029

[17] Arifuzzaman, M., Karim, M.R., Siddiquee, T.A., Mirza, A.H. and Ali, M.A. (2013) Synthesis and Characterization of Some Schiff Bases formed by Condensation of 2, 9-Phenathroline-1,10-Dialdehyde with Sulfur-Containing Amines. International Journal of Organic Chemistry, 3, 81-86. https://doi.org/10.4236/ijoc.2013.31009

[18] Jaman, Z., Karim, M.R., Dumenyo, K. and Mirza, A.H. (2014) Antibacterial Activities of New Schiff Bases and Intermediate Silyl Compounds Sythesized from 5-Substituted-1,10-Phenanthroline-2,9-Dialdehyde. Advances in Microbiology, 4, 1140-1153. https://doi.org/10.4236/aim.2014.415124

[19] Thiele, S., Malmgaard-Clausen, M., Engel-Andreasen, J., Steen, A., Rummel, P.C., Nielsen, M.C., Gloriam, D.E., Frimurer, T.M., Ulven, T. and Rosenkilde, M.M. (2012) Modulation in Selectivity and Allosteric Properties of Small-Molecule Ligands for CC-Chemokine Receptors. Journal of Medicinal Chemistry, 55, 81648177. https://doi.org/10.1021/jm301121j

[20] Lewis, F.W., Harwood, L.M., Hudson, M.J., Drew, M.G.B., Desreux, J.F., Vidick, G., Bouslimani, N., Modolo, G., Wilden, A., Sypula, M., Vu, T. and Simonin, J. (2011) Highly Efficient Separation of Actinides from Lanthanides by a Phenanthroline-Derived BisTriazine Ligand. Journal of the American Chemical Society, 133, 13093-13102. https://doi.org/10.1021/ja203378m

[21] Musetti, C., Lucatello, L., Bianco, S., Krapcho, A.P., Cadamuro, S.A., Palumbo, M. and Sissi, C. (2009) Metal Ion-Mediated Assembly of Effective Phenanthroline-Based G-Quadruplex Ligands. Dalton Transactions, 19, 3657. https://doi.org/10.1039/b904630p

[22] Ziessel, R., Nguyen, P., Douce, L., Cesario, M. and Estournes, C. (2004) Selective 
Oxidation of a Single Primary Alcohol Function in Oligopyridine Frameworks. Organic Letters, 6, 2865-2868. https://doi.org/10.1021/ol0491843

[23] Ye, Y., Sun, Y., Zhao, H., Lan, M., Gao, F., Song, C., Lou, K., Li, H. and Wang, W. (2013) A Novel Lactoferrin-Modified $\beta$-Cyclodextrin Nanocarrier for Brain-Targeting Drug Delivery. International Journal of Pharmaceutics, 458, 110-117. https://doi.org/10.1016/j.ijpharm.2013.10.005

[24] Liu, Y., Jin, L. and Zhang, H. (2002) Inclusion Complexation Thermodynamics of Acridine Red and Rhodamine B by Natural and Novel Oligo (Ethylenediamine) Tethered Schiff Base $\beta$-Cyclodextrin. Journal of Inclusion Phenomena and Macrocyclic Chemistry, 42, 115-120. https://doi.org/10.1023/A:1014569532163 


\section{Appendix}

${ }^{1} \mathrm{H}$ NMR of 1,10-Phenanthroline-2,9-dihydroxymethyl (Compound 9)

SpinWorks 4: NR ald to di ol $\square \square$ A_PROTON.TSU DMSO \{C:\Bruker\TopSpin3.0\NMR_data\Karim_group \mkarim\} mkarim 1

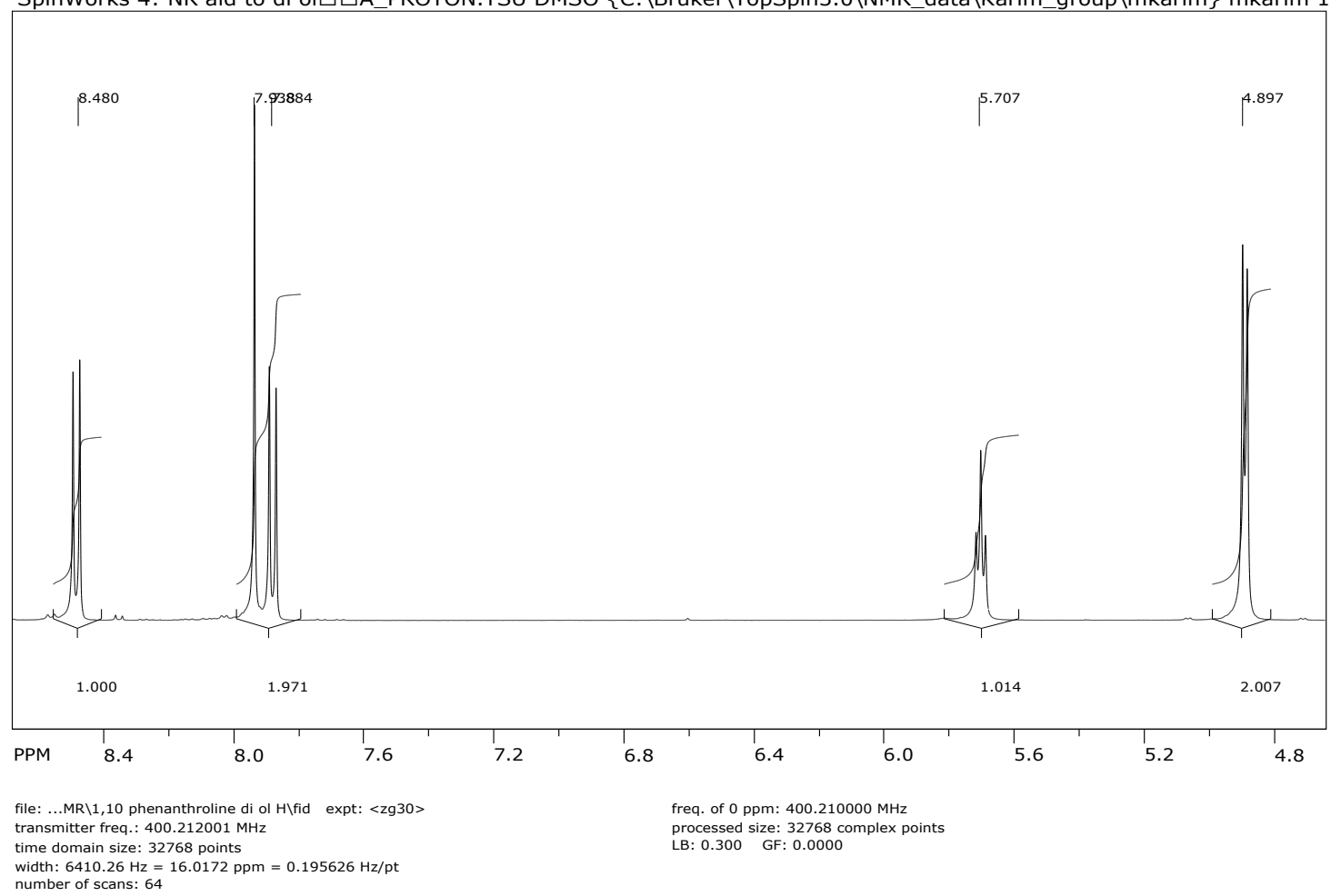

${ }^{13} \mathrm{C}$ NMR of 1,10-Phenanthroline-2,9-dihydroxymethyl (Compound 9)

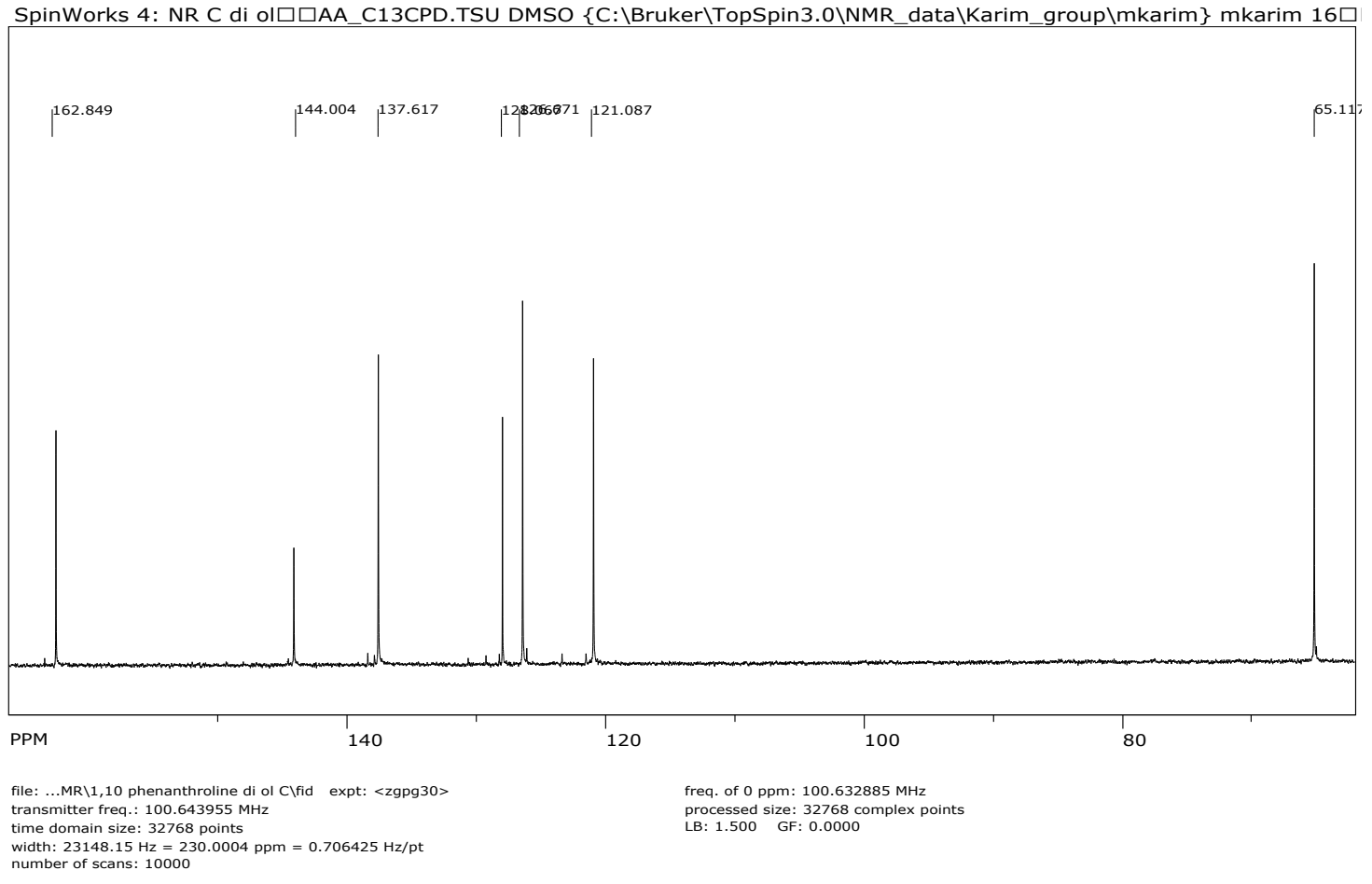


${ }^{1} \mathrm{H}$ NMR of 1,10-Phenanthroline-9-dihydroxymethyl-2-Carboxyladehyde (Compound 3)



${ }^{1} \mathrm{H}$ NMR of 1,10-Phenanthroline-9-dihydroxymethyl-2-Carboxyladehyde (Compound 3)-Aromatic moiety

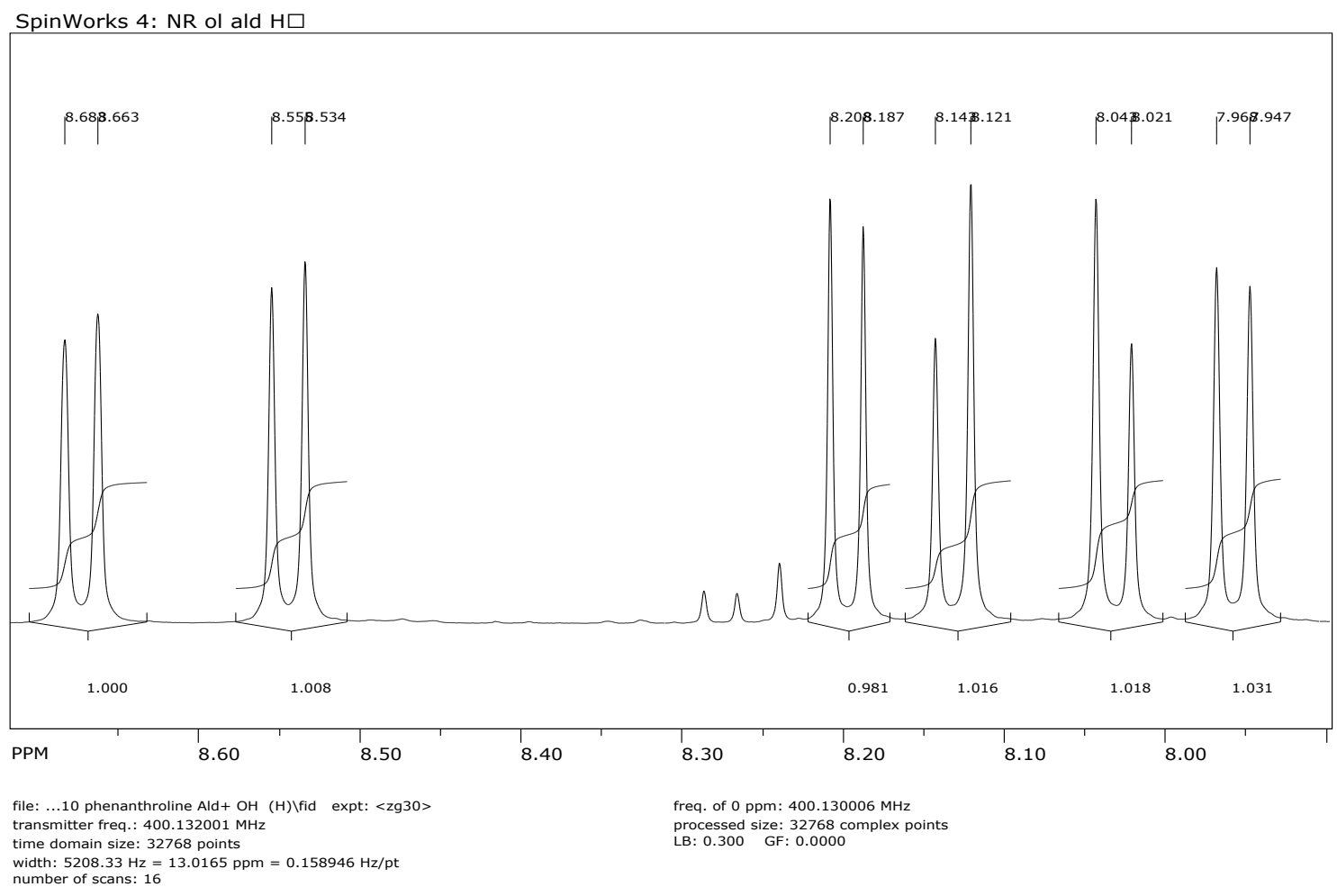


${ }^{13} \mathrm{C}$ NMR of 1,10-Phenanthroline-9-dihydroxymethyl-2-Carboxyladehyde (Compound 3)

SpinWorks 4: NR ol ald C $\square$

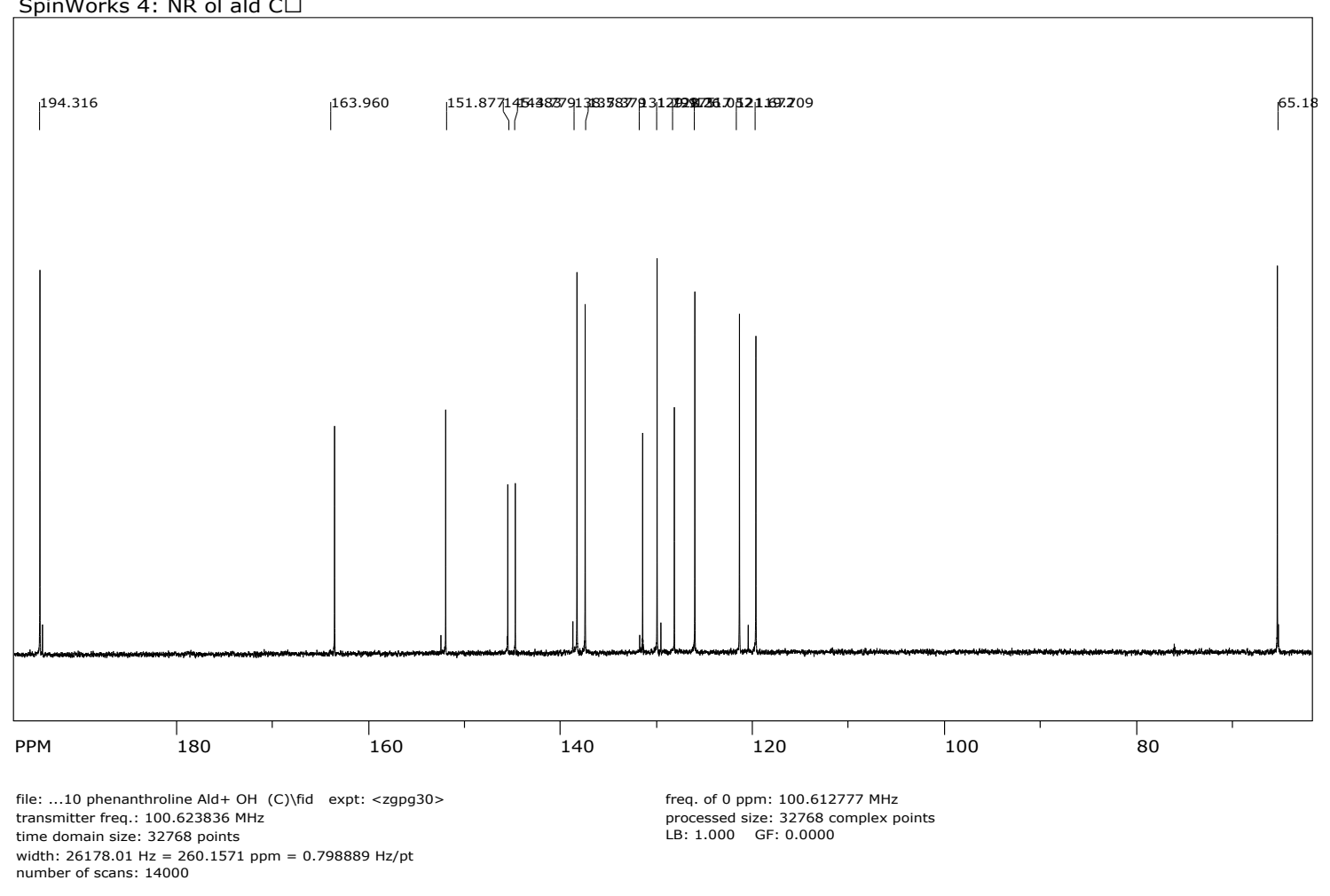

${ }^{1} \mathrm{H}$ NMR of Folic Acid Chloride (Compound 5)

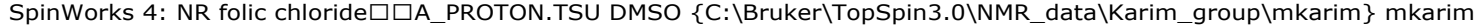




${ }^{13} \mathrm{C}$ NMR of Folic Acid Chloride (Compound 5)

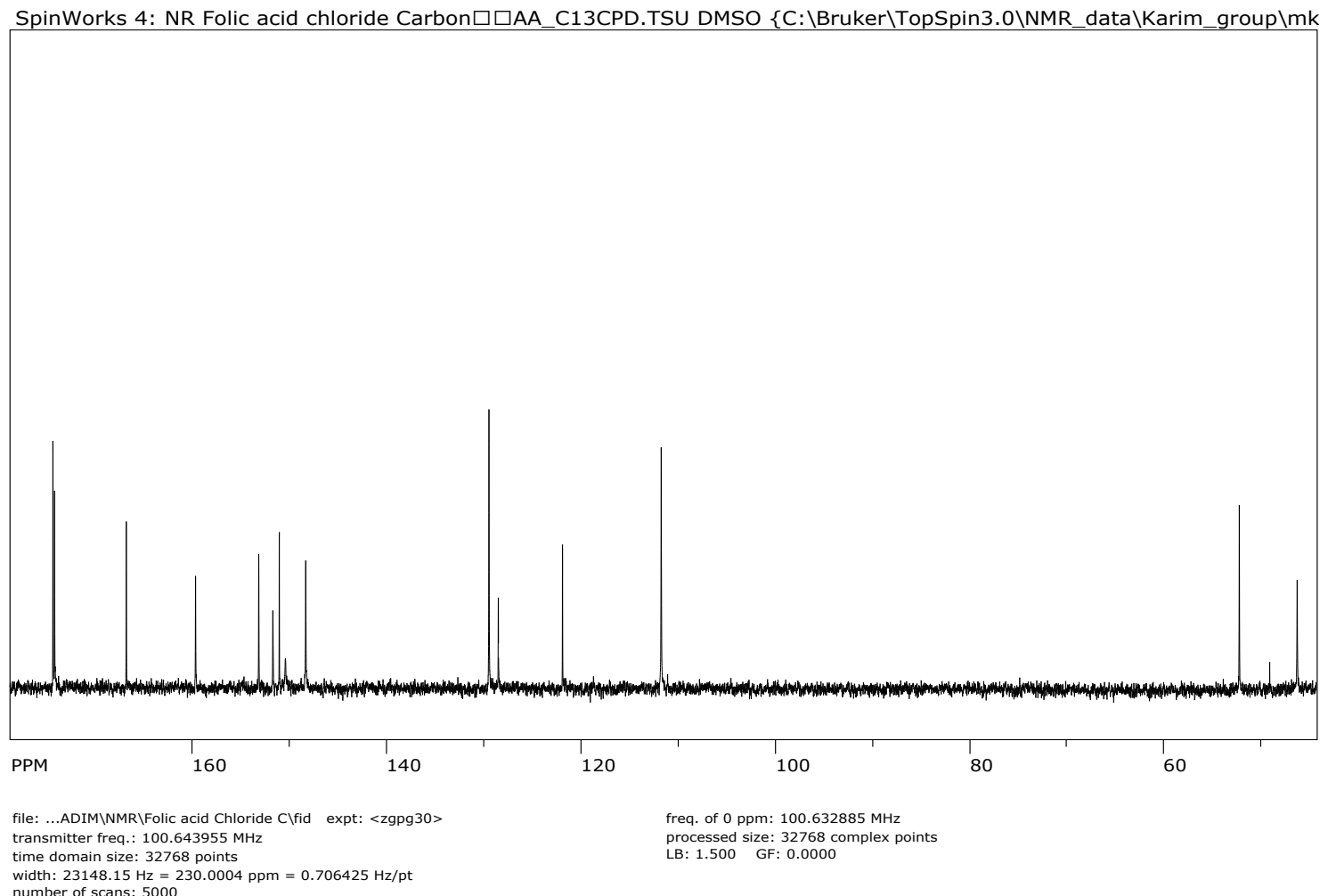

width: $23148.15 \mathrm{~Hz}=230.0004 \mathrm{ppm}=0.706425 \mathrm{~Hz} / \mathrm{pt}$

${ }^{1} \mathrm{H}$ NMR6-OTs- $\beta$-CD (Compound 7)

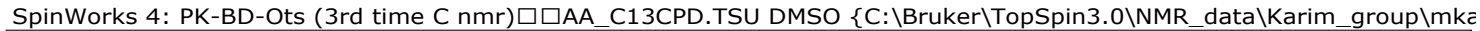




13C NMR of 6-OTs- $\beta$-CD (Showing OTs group only)

SpinWorks 4: NR BCDTsCI $\square \square$ A_PROTON.TSU DMSO \{C:\Bruker\TopSpin3.0\NMR_data\Karim_group\mkarim\} mkarim 4 $\square$



${ }^{1} \mathrm{H}$ NMR of EDA- $\beta$-CD (Compound 4)

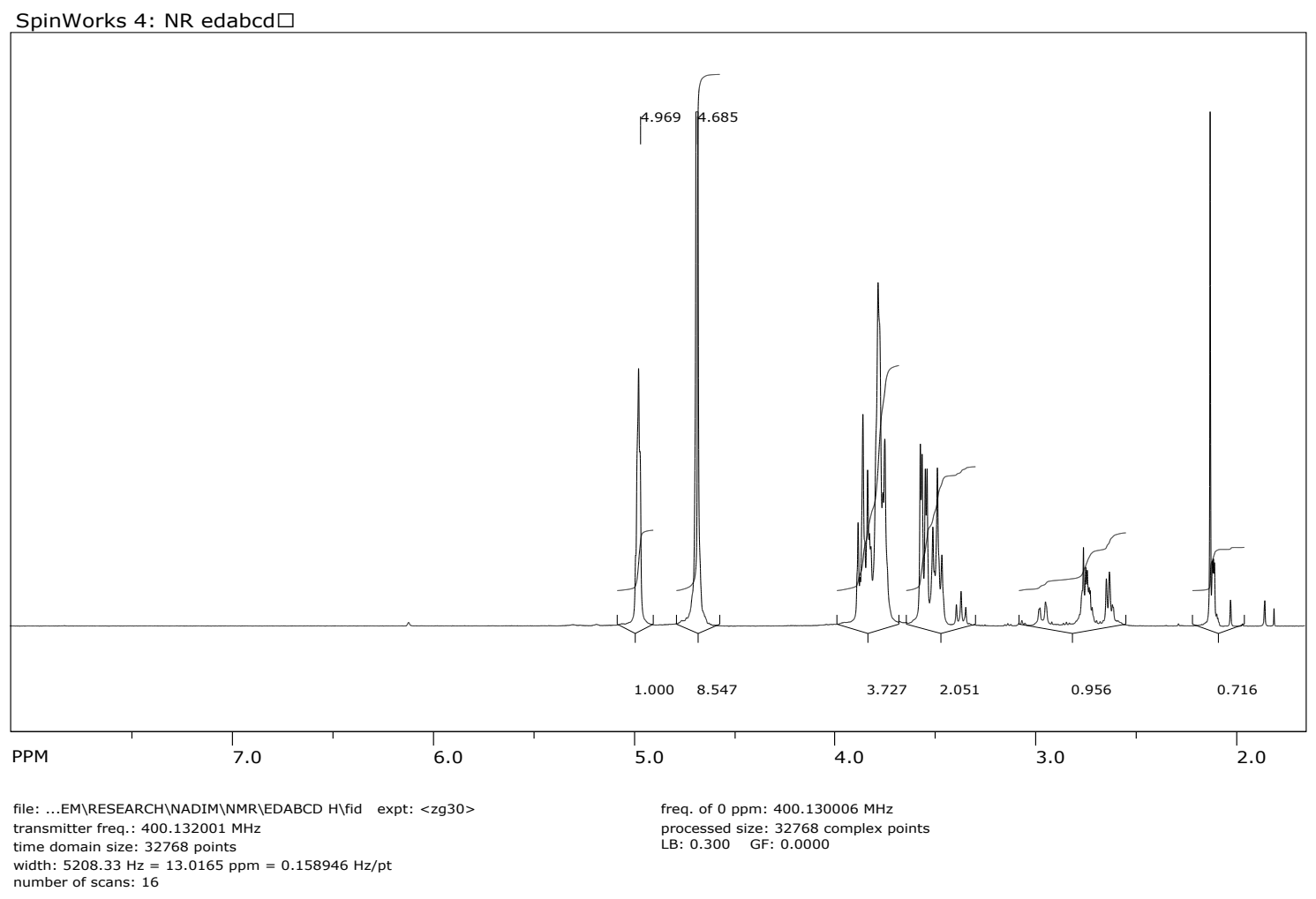




\section{${ }^{13} \mathrm{C}$ NMR of EDA- $\beta$-CD (Compound 4)}

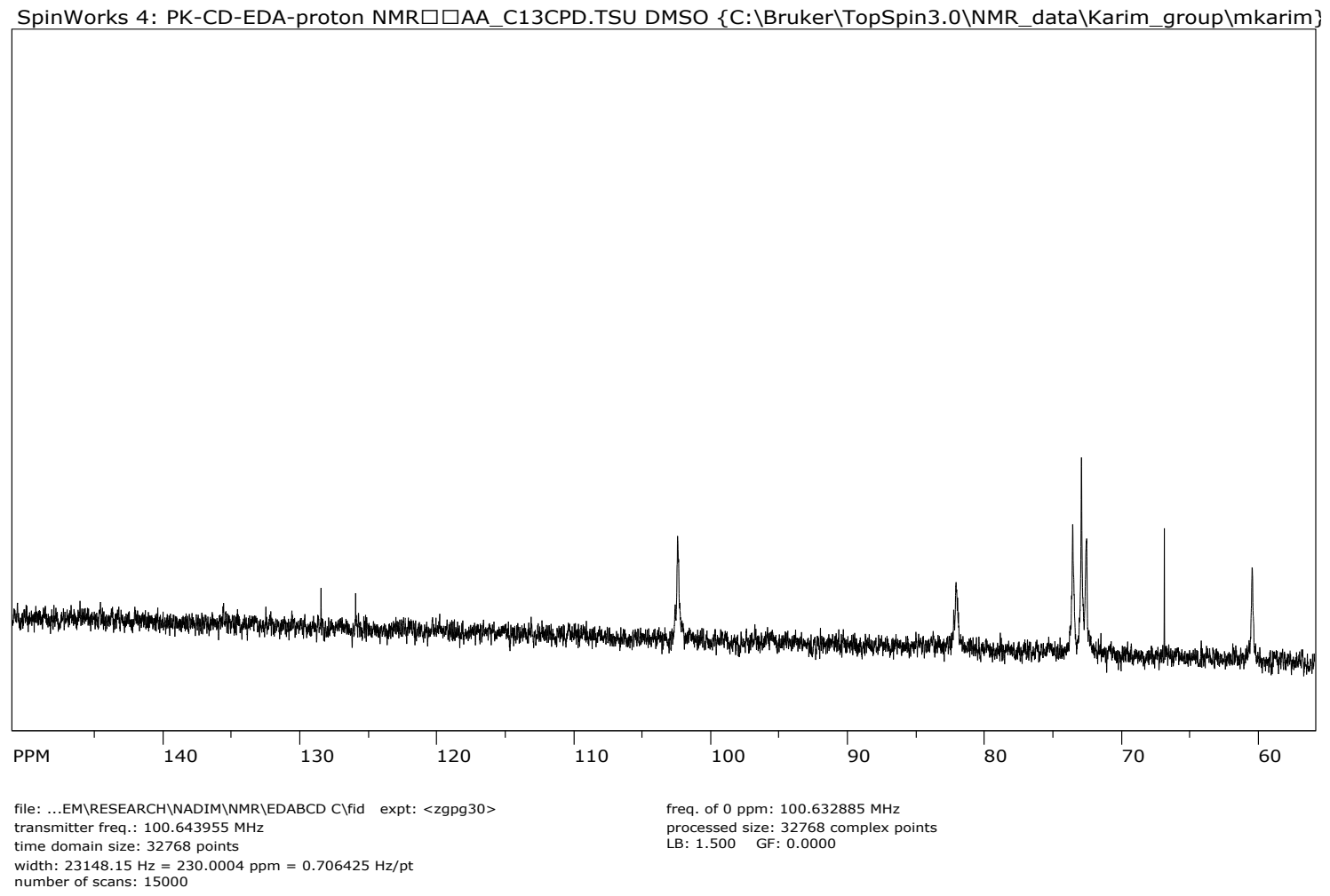

${ }^{1} \mathrm{H}$ NMR of Compound 12

SpinWorks 4: NR edabcd+fur(schiff ethanol) $\square$




${ }^{1} \mathrm{H}$ NMR of Compound (NKS-2)

SpinWorks 4: NR FaCL+EDABCD Fur $\square$

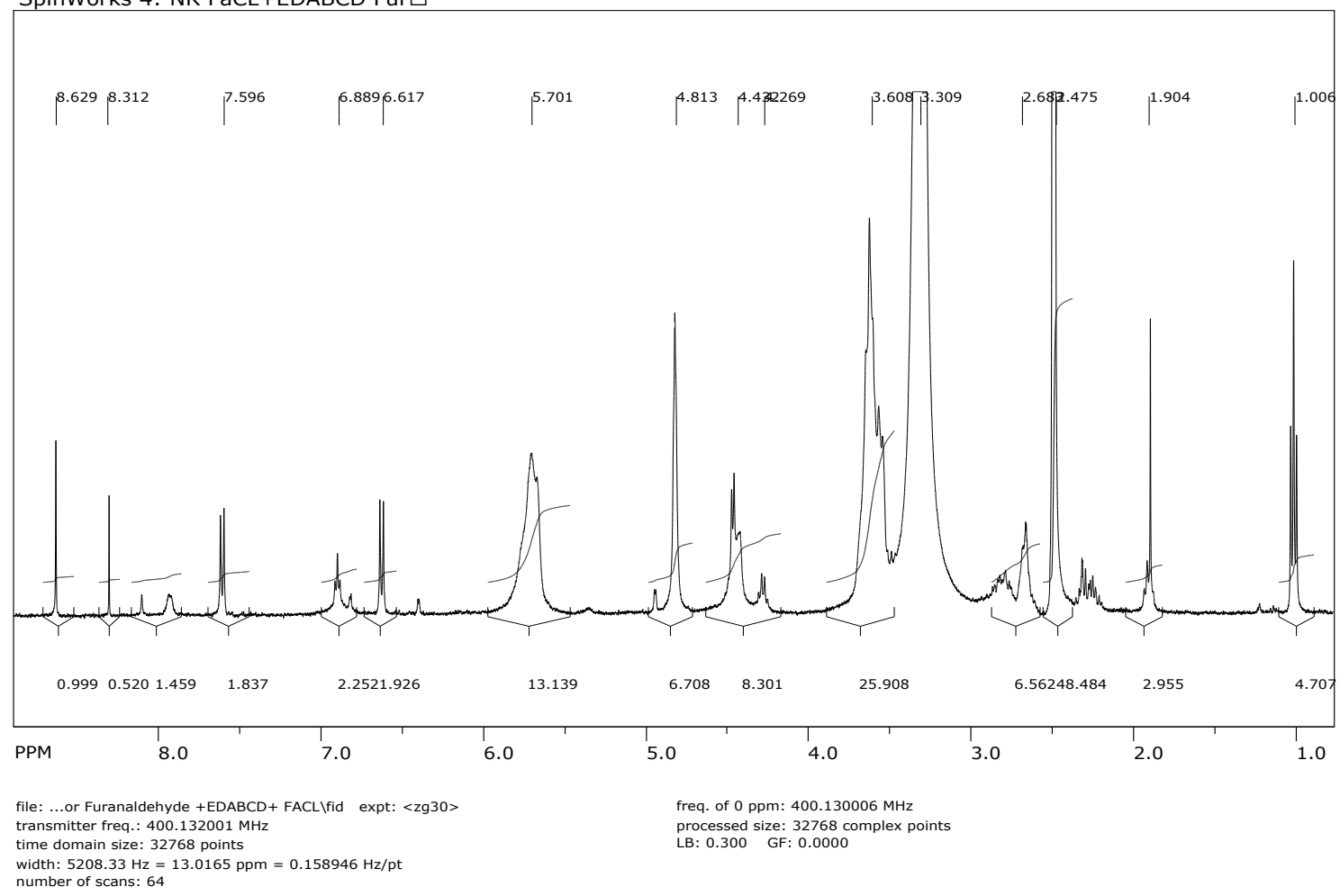

${ }^{1} \mathrm{H}$ NMR of NKS-1

SpinWorks 4: NR 1,10 final $\square$

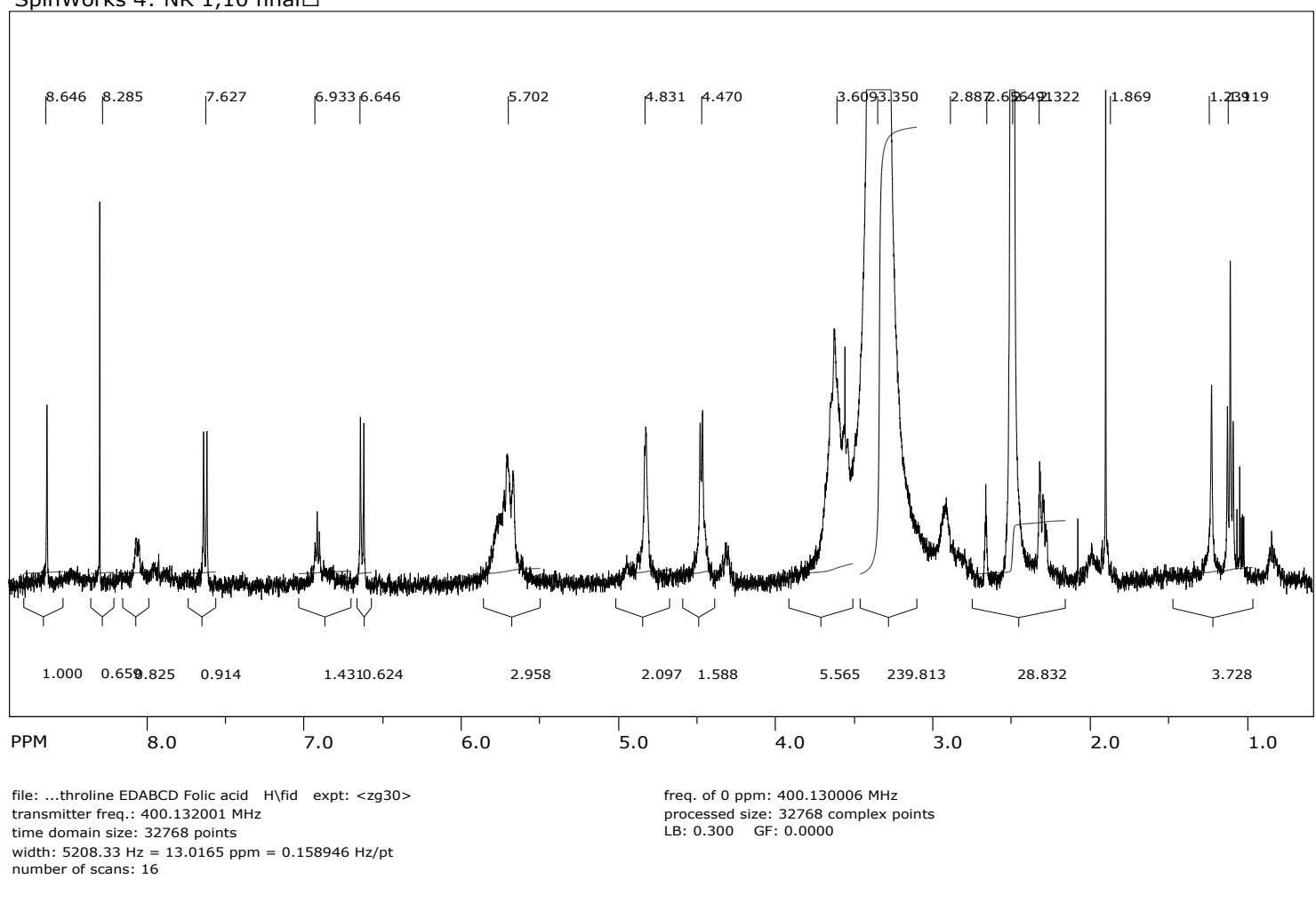

